\title{
PRIMARY RHABDOMYOSARCOMA OF THE DIAPHRAGM: CASE REPORT AND LITERATURE REVIEW
}

Cleverson Winston de Liz Medeiros, William Kondo, Ivo Baptista Júnior, Alvo Orlando Vizzotto Júnior, Lúcia de Noronha and Calixto Antonio Hakim Neto

MEDEIROS CW de L et al. - Primary rhabdomyosarcoma of the diaphragm: case report and literature review. Rev. Hosp. Clín. Fac. Med. S. Paulo 57(2):67-72, 2002.

The authors report a case of primary rhabdomyosarcoma of the diaphragm, an extremely rare presentation with only 14 cases reported in the literature.

An 18-year-old male presented 2 spontaneous occurrences of pneumothorax. Computed tomography and magnetic resonance showed a tumoral mass on the right diaphragmatic surface, and after biopsy, the diagnosis was compatible with spindle cell rhabdomyosarcoma. Because the visceral pleura was invaded by the tumoral mass, a right pleuropneumonectomy was performed. The patient received adjuvant chemotherapy, and there was no evidence of disease 15 months after the operation.

Based on the Intergroup Rhabdomyosarcoma Study Group (IRSG) criteria, which consider the extent of the disease and its surgical resectability, rhabdomyosarcomas can be classified into 4 groups. In clinical group I, which was the classification of our patient, the tumor is localized and completely resectable, which implies a good prognosis. Rhabdomyosarcoma is a rare tumor, and a good outcome may result if it is completely resected.

DESCRIPTORS: Rhabdomyosarcoma. Sarcoma. Diaphragm. Embryonal. Adolescent.

Rhabdomyosarcoma (RMS) is a malignant tumor arising in skeletal muscle, and it is the most common soft-tissue sarcoma in children and adolescents, accounting for $15 \%$ of soft-tissue sarcomas in the general population and $4 \%$ to $8 \%$ of all childhood malignancies ${ }^{1}$.

There are 4 histologic subtypes of RMS: pleomorphic, alveolar, botryoid, and embryonal, the latter being the most frequently occurring soft-tissue sarcoma in childhood. The head and neck region and urogenital tract are most common sites of presentation ${ }^{1-3}$. The embyonal tumor is occasionally found in adults and the elderly. Primary rhabdomyosarcomas of the diaphragm are extremely rare tumors, with only 14 cases reported in the literature.

We present a case of diaphragmatic spindle cell embryonal rhabdomyosarcoma in a young male.

\section{CASE REPORT}

An 18-year-old male presented with dyspnea and ventilatory-dependent pain at the posterior region of the right hemithorax. He had experienced

From Hospital Nossa Senhora das Graças, Curitiba, Paraná.
2 spontaneous occurrences of pneumothorax, and during the second one (one year before admission to our department) a thoracotomy with biopsy and pneumothorax drainage were performed. Histologic examination was negative for malignancy. Physical examination showed reduced breath sounds at the right hemithorax.

CT scan (Fig. 1) demonstrated the presence of a 5-cm solid mass on the right pleural surface, extending to the right posterior mediastinum. He underwent videothoracoscopy with biopsy; microscopic exam revealed a spindle cell embryonal RMS, and immunohistochemical findings confirmed it. 


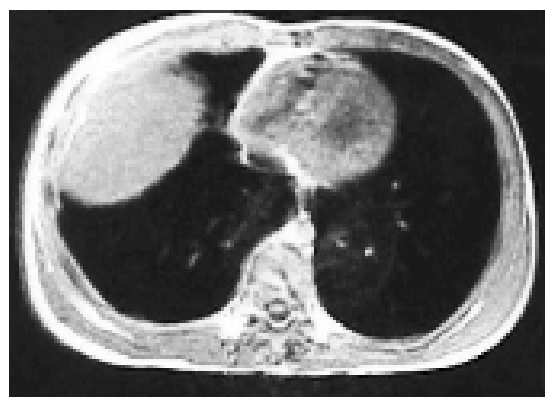

Figure 1 - CT scan showing a mass in right hemithorax.

Magnetic resonance (Fig. 2) showed an extensive lesion, with the largest diameter of $5 \mathrm{~cm}$, at the base of the right hemithorax compressing the hepatic surface and extending to the right mediastinum.

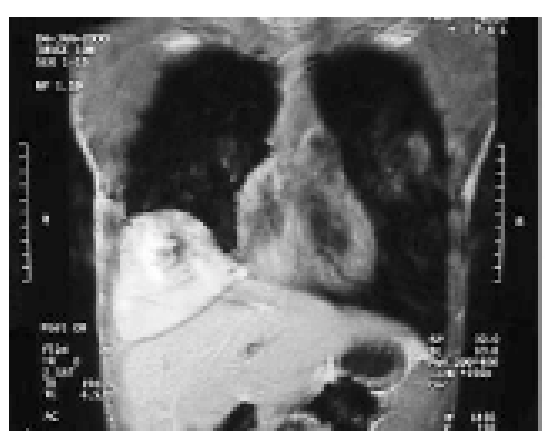

Figure 2 - Magnetic resonance showing a mass in right hemithorax.

During right thoracotomy, a diaphragmatic mass was identified, and multiple contiguous implants in the visceral and parietal pleura were noticed. Because of the extent of the lesion, a right pleuropneumonectomy and partial resection of diaphragmatic muscle with primary suture was performed. Histologic examination (Figs. $3 \mathrm{a}$ and $3 \mathrm{~b}$ ) revealed a poorly differentiated spindle cell sarcoma, compatible with spindle cell embryonal rhabdomyosarcoma, without nodal metastasis in the mediastinum.

The postoperative course was uneventful, and the patient was discharged from the hospital on the ninth postoperative day. Adjuvant chemotherapy with doxorubicin, ifosfamide, and dacarbazine was initiated.
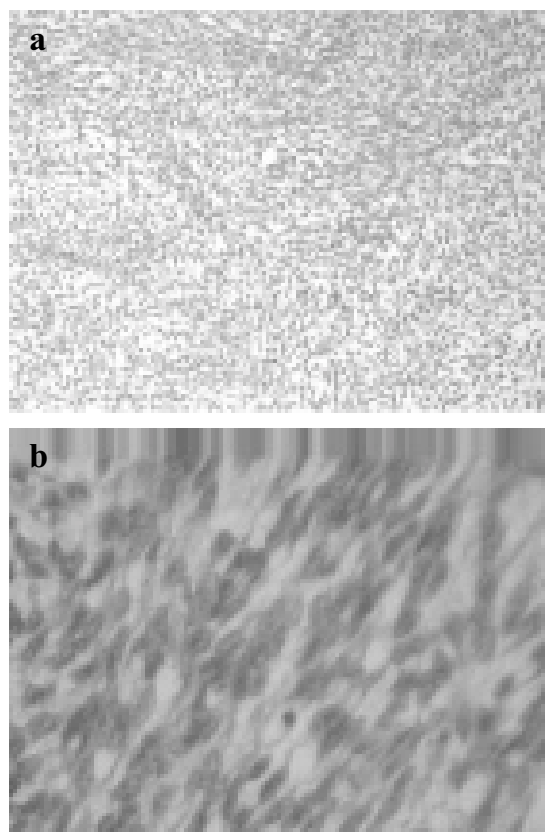

Figures 3a and 3b - Tumor tissue with bundles of primitive mesangial cells similar to myoblasts. Spindle-shaped cells with eosinophilic cytoplasm and elongated nuclei with dense chromatin (HEx40 e HEx100).

Eleven months after surgery, a routine CT scan showed a probable recurrence of the tumor on the diaphragm. The patient underwent another thoracotomy revealing only a hematoma in the thoracic wall and intense local fibrosis. Resection of the hematoma and curettage of the thoracic wall were performed. Microscopic evaluation did not show recurrent disease.

At the follow-up evaluation 15 months after surgery, no evidence of disease was found.

\section{DISCUSSION}

Rhabdomyosarcoma (RMS) is the most frequently occurring soft tissue sarcoma in children and young adults and has been divided into 4 histologic subtypes: embryonal (58\%), botryoid (subtype of embryonal, corresponding to 10 percent of RMSs), alveolar (14\%), and pleomorphic $(16 \%)^{3,4}$.

Rhabdomyosarcoma may occur at any site, but primary tumors are more commonly located in head and neck (42\%), urogenital tract (34\%), and extremities $(11 \%)^{3}$. Alveolar tumors tend to occur primarily in trunk and extremities, whereas embryonal tumors are more often found in the head and neck or genitourinary and paratesticular sites 5 .

Primary tumors of the diaphragm are uncommon entities, and diaphragmatic rhabdomyosarcoma is an extremely rare tumor 6 . Table 1 shows all 14 cases of primary RMSs of the diaphragm that have been reported since 1939.

In general, diaphragmatic tumors, either benign or malignant, do not express any symptom at the onset ${ }^{10}$. Our patient experienced 2 spontaneous occurrences of pneumothorax, which led us to start an investigation.

In contrast to the pediatric population, RMS in adults is comparatively rare, with the alveolar subtype predominating in adult patients 25 years of age or less, and the pleomorphic subtype predominating in adult patients over the age of $25^{12}$.

Somatically acquired mutations underlie all forms of human cancer, but until recently, little was known about those associated with rhabdomyosarcoma. Cytogenetic and molecular genetic studies have identified both nu-

Table 1 - Primary rhabdomyosarcoma of the diaphragm.

\begin{tabular}{lll}
\hline Author & Year & $\begin{array}{l}\text { Number } \\
\text { of cases }\end{array}$
\end{tabular}

\begin{tabular}{lll}
\hline Ryan $^{7}$ & 1939 & 1 \\
Peery \& Smith $^{7}$ & 1939 & 1 \\
Weiner \& Chow $^{6}$ & 1965 & 2 \\
Olafasson et al. $^{6}$ & 1971 & 2 \\
Hein $^{6}$ & 1974 & 1 \\
Federici et al. $^{6}$ & 1985 & 1 \\
Federici et al. $^{8}$ & 1986 & 1 \\
Vaño et al. $^{9}$ & 1988 & 1 \\
Rea et al. & 1992 & 1 \\
Eustace S \& Fitzgerald & 1993 & 1 \\
Midorikawa et al. & & 10 \\
Gupta et al. & 1998 & 1 \\
\hline TOTAL & 1999 & 1 \\
\hline
\end{tabular}


merical and structural abnormalities of tumor-cell chromosomes. Recurrent chromosomal translocations, including $\mathrm{t}(2 ; 13)(\mathrm{q} 35 ; \mathrm{q} 14)$ and less commonly $\mathrm{t}(1 ; 13)(\mathrm{p} 36 ; \mathrm{q} 14)$, have been identified in most cases of alveolar rhabdomyosarcoma ${ }^{13-15}$. The $\mathrm{t}(2 ; 13)$ translocation results in fusion of part of the PAX3 gene to part of the FKHR gene, leading to formation of the PAX3-FKHR gene that encodes a chimeric protein. In case of $\mathrm{t}(1 ; 13)$ translocation, the PAX7-FKHR gene is formed ${ }^{14-16}$. The chimeric transcript may be detected by reverse transcription followed by polymerase chain reaction $(\mathrm{PCR})^{17}$. Studies have suggested that clinical features, natural history of disease, and response to therapy differ in subgroups of patients according to the presence of $\mathrm{t}(2 ; 13)$ or $\mathrm{t}(1 ; 13)$ translocation or the absence of both translocations ${ }^{15}$.

Some gene alterations other than PAX3/7-FKHR fusion might be markers of aggressiveness of RMSs. Alterations of the tumor suppressor p53 gene are the most frequent gene alterations in human cancer. These alterations are related to poor prognosis in several cancers including soft-tissue sarcomas in adults ${ }^{18}$.

Cytogenetic and molecular abnormalities related to embryonal RMSs include hyperdiploidy ${ }^{19}$, trisomy of chromosomes 2, 13, and $18^{20}$, and loss of heterozygosity for polymorphic markers at $11 \mathrm{p} 15.5$ and $16 \mathrm{q}^{20}$. Other mutations or amplifications of tumorsuppressor genes, oncogenes, or tumorspecific fusion genes (e.g., p53, N-ras, $\mathrm{K}$-ras and $\mathrm{N}-m y c$ ) are frequently observed and may be involved in the pathogenesis of rhabdomyosarcoma or may represent secondary events related to progression of the tumor ${ }^{13,20}$.

The Intergroup Rhabdomyosarcoma Study Group (IRSG) is the major worldwide protocol study group of rhabdomyosarcomas, and since 1972 , has been conducting sequential prospective studies of these tumors. By
1998, these studies had included more than 3000 children, which comprised about three-fourths of all patients in North America ${ }^{21}$. According to the IRSG, rhabdomyosarcomas are divided into 4 surgical-histopathologic groups, based on the extent of disease, surgical decision, and extent of resection (Table 2) ${ }^{1}$. The international literature has been using this classification system for establishment of treatment and prognosis for patients with $\mathrm{RMS}^{1,2}$.

Table 2 - IRSG surgical-pathologic grouping system ${ }^{2}$.

\begin{tabular}{ll}
\hline Group I & $\begin{array}{l}\text { Localized disease, completely } \\
\text { resected }\end{array}$ \\
Group II & $\begin{array}{l}\text { Microscopic disease remaining } \\
\text { with or without completely } \\
\text { resected regional nodal disease }\end{array}$ \\
Group III & $\begin{array}{l}\text { Incomplete resection or biopsy } \\
\text { with gross residual disease }\end{array}$ \\
Group IV & $\begin{array}{l}\text { Distant metastases present at } \\
\text { onset }\end{array}$ \\
\hline
\end{tabular}

In all intergroup rhabdomyosarcoma studies (IRS), patients were randomized or assigned to therapy according to clinical group and received chemotherapy associated or not with radiotherapy (RT) after surgery. Therefore, prognostic factors and indications for RT and chemotherapy for different subtypes of RMS could be defined. In both IRS-I and IRS-II, survival at 5 years decreased from approximately $82 \%$ in patients with localized tumors that could be removed by surgery (clinical group I) to approximately $24 \%$ in patients with metastatic disease (clinical group IV). These results emphasize the crucial role of disease extent (i.e., clinical group) in predicting survival $^{1}$.

For patients with group I embryonal tumors, primary tumor location was strongly associated with outcome. Patients with tumors arising in genitourinary and paratesticular locations had a good prognosis ${ }^{1,5}$, whereas patients with disease in the extremities had relatively poor survival ${ }^{1}$. No differences at outcome were observed when considering age, sex, study, or whether or not the patient received RT ${ }^{5}$. In IRSI, patients with tumors larger than $5 \mathrm{~cm}$ in diameter had the poorest survival experience; tumor size was not related to survival in IRS-II ${ }^{1}$. Considering only histology and survival, patients with alveolar tumors fared the worst (5-year survival, $47 \%$ in IRS-I and $57 \%$ in IRS-II), whereas patients with botryoid or embryonal tumors had the best survival $\left(95 \%\right.$ and $92 \%$, respectively) ${ }^{1}$. Estimated 10-year failure-free survival for patients with group I embryonal RMS was $92 \%$ in IRS-I and $81 \%$ in IRS-II ${ }^{5}$. The effect of RT on outcome was analyzed according to tumor histology for patients treated on IRS-I, II, and III, and no benefit was found for patients with group I embryonal RMS ${ }^{5}$.

The patient in our study presented a mass on right diaphragm with contiguous implants in the parietal and visceral pleura. He underwent right pleuropneumonectomy with partial resection of the diaphragm. The decision was made to perform right lung resection because of the impairment of the visceral pleura. Using the IRSG criteria, this patient was classified as group I, since this group includes patients with complete tumoral resection without clinical and/or radiographic evidence of distant or nodal metastases. His histologic subtype (embryonal) and his clinical group are predictors of good prognosis. However, the size of tumor and its location were indicators of poor outcome.

The American Joint Committee for Cancer Staging (AJCC) system can also be used for staging patients with RMS and relies on histologic grade $(\mathrm{G})$, tumor size $(\mathrm{T})$, nodal status $(\mathrm{N})$, and the presence or absence of distant metastases $(\mathrm{M})^{22}$. According to this system, the patient would be classified as stage III. Nevertheless, the IRSG 
staging system was used, since this group studies only rhabdomyosarcoma and this classification system is specific for this kind of tumor.

For unresectable local or regional tumors in less favorable sites, radiation therapy is recommended early in the course of treatment ${ }^{21}$. Radiation therapy was not performed because our patient did not fit in these criteria.

Neoadjuvant chemotherapy was not used because IRSG protocols still had not established the role of this therapeutic modality when our patient was treated; until IRS-III was completed, no protocol recommended neoadjuvant chemotherapy as the gold standard.

The classification of our patient into group I was based in the absence of compromised surgical margins in the resected mass; nevertheless, due to the size of the tumor, classification into group II cannot be totally excluded. However, this change in clinical group would not change the adjuvant treatment administered. Although IRS-IV recommends RT with $4100 \mathrm{cGy}$ at week 9 (day 62) after surgery for group II patients, our patient could not receive this therapeutic regimen because a right deviation of the mediastinum had occurred. Because of the size of the tumor, we would have had to irradiate the entire right hemithorax from the diaphragmatic surface to the upper lobe of the lung. This irradiation would probably had affected the contralateral lung, the heart, and other deviated structures of the mediastinum in higher doses than these organs can tolerate.
We should also note that until IRS-IV was completed in 2000 (and which was ongoing at the time our patient was being treated), IRSG protocols did not show a benefit from using postoperative RT with patients with group I tumors. Nowadays, it is believed that radiation therapy may benefit group I patients who have a less favorable prognosis (e.g., alveolar histology) ${ }^{23}$.

For patients with embryonal rhabdomyosarcoma in a site associated with a favorable outcome (i.e., the head and neck, but not the parameningeal area and the entire genitourinary tract except for the bladder and prostate) who have undergone complete or nearly complete resection (with only microscopic residual tumor), treatment with VA (vincristine and dactinomycin) is indicated according to IRSG protocols ${ }^{21,24}$. However, patients with alveolar tumors require the addition of cyclophosphamide to the regimen. The cure rate among such low-risk patients is 90 to 95 percent, and about one-third of patients with newly diagnosed rhabdomyosarcoma belong to this low-risk group ${ }^{13,16}$. Patients with all types of gross residual tumor, except orbital tumors, are considered to be at intermediate risk, with a cure rate of 70 to 80 percent, requiring more intensive chemotherapy that includes at least 3 drugs (vincristine, dactinomycin, and cyclophosphamide $)^{13,16}$. The fourth IRS compared VAC (vincristine, dactinomycin, and cyclophosphamide), VAI (vincristine, dactinomycin, and ifosfamide) and VIE (vincristine, ifosfamide, and etoposide) regimens and demonstrated no advantage in substituting cyclophosphamide for ifosfamide or dactinomycin for etoposide in the 3-drug chemotherapy regimen $^{25}$. The fifth IRS is exploring use of these 3 drugs plus topotecan, the pioneer of the new class of anticancer agents, topoisomerase I inhibitors. The overall response to topotecan was $46 \%$ in patients with metastatic disease, and the response was better in alveolar tumors $(65 \%)$ than in embryonal tumors $(28 \%)^{26}$.

Our patient received MAID (mesna, doxorubicin, ifosfamide, and dacarbazine) chemotherapy postoperatively, which is the first choice for sarcoma because it includes the two most effective drugs against this tumor (ifosfamide and doxorubicin $)^{27}$. In spite of good responses of this combination, sometimes VAC may replace MAID regimen, as observed in IRSG protocols. Although less effective, the VAC regimen does not cause heart toxicity induced by doxorubicin.

Rhabdomyosarcoma is a malignant tumor that can arise at any site of the organism. Signs and symptoms depend on the anatomic site of the tumor, and prognosis varies according to tumor size, histology, localization, clinical group, and cytogenetic alterations. Better supportive care and systematic application of increasingly effective multimodal treatment have dramatically improved survival over this period, with 5-year survival rates rising from approximately 10 to 20 percent in 1970 to about 60 to 70 percent currently. 
MEDEIROS CW de L e col. Rabdomiossarcoma primário de diafragma: relato de caso e revisão da literatura. Rev. Hosp. Clín. Fac. Med. S. Paulo 57(2):67-72, 2002.

Os autores relatam um caso de rabdomiossarcoma primário de diafragma, uma apresentação extremamente rara, com apenas 14 casos descritos na literatura mundial.

D.K., masculino, 18 anos, apresentou 2 episódios de pneumotórax espontâneo. Tomografia computadorizada e ressonância magnética evidenciaram massa em superfície diafragmática direita; após biópsia o diagnóstico foi compatível com rabdomiossarcoma embrionário tipo fusocelular, sendo realizada pleuropneumonectomia direita devido à presença de implante tumoral em pleura visceral. Ele recebeu quimioterapia adjuvante e se encontra livre de doença 15 meses após a cirurgia.

Os rabdomiossarcomas podem ser divididos em quatro grupos cirúrgicopatológicos, baseados nos critérios do Intergroup Rhabdomyosarcoma Study
Group (IRSG) que levam em consideração a extensão da doença e a decisão cirúrgica; no grupo I (como no caso aqui relatado) os pacientes possuem doença localizada completamente ressecada, apresentando o melhor prognóstico.

O rabdomiossarcoma é um tumor raro, podendo ter bom prognóstico quando totalmente ressecado.

DESCRITORES: Rabdomiossarcoma. Sarcoma. Diafragma. Embrionário. Adolescente.

\section{REFERENCES}

1. CRIST WM, GARNSEY L, BELTANGADY MS et al. - Prognosis in children with rhabdomyosarcoma: a report of the intergroup rhabdomyosarcoma studies I and II. J Clin Oncol 1990; 8(3): 443452.

2. PAPPO AS, ANDERSON JR, CRIST WM et al. - Survival after relapse in children and adolescents with rhabdomyosarcoma: A report from the Intergroup Rhabdomyosarcoma Study Group. J Clin Oncol 1999; 17(11):3487-3493.

3. WIJNAENDTS LC, VAN DER LINDEN JC, VAN UNNIK AJ et al. Histopathological classification of childhood rhabdomyosarcomas: relationship with clinical parameters and prognosis. Hum Pathol 1994; 25(9):900-907.

4. HORN RC \& ENTERLINE HT - Rhabdomyosarcoma: A clinicopathological study and classification of 39 cases. Cancer 1958; 11:181-199.

5. WOLDEN SL, ANDERSON JR, CRIST WM et al. - Indications for radiotherapy and chemotherapy after complete resection in rhabdomyosarcoma: A report from the Intergroup Rhabdomyosarcoma Studies I to III. J Clin Oncol 1999; 17(11):3468-3475.

6. REA F, LOY M, BONAVINA L et al. - Primary rhabdomyosarcoma of the diaphragm. Report of a case presenting with hemothorax. Thorac Cardiovasc Surg 1992; 40(4): 201-203.
7. EUSTACE S \& FITZGERALD E - Primary rhabdomyosarcoma of the diaphragm: an unusual cause of adolescent pseudo-achalasia. Pediatr Radiol 1993; 23(8):622-623.

8. FEDERICI S, CASOLARI E, ROSSI F et al. - Rhabdomyosarcoma of the diaphragm in a 4-year-old girl. Z Kinderchir 1986; 41(5):303305.

9. VAÑO J, FERNANDEZ L \& MAYAYO E - Primary rhabdomyosarcoma of the diaphragm in a 4-year-old child. Favourable course 5 years after surgery and chemotherapy. Ann Chir 1988; 42(8):617-619.

10. MIDORIKAWA Y, KUBOTA K, MORI M et al. - Rhabdomyosarcoma of the diaphragm: report of an adult case. Jpn J Clin Oncol 1998; 28(3):222-226.

11.GUPTA AK, MITRA DK \& BERRY M - Primary embryonal rhabdomyosarcoma of the diaphragm in a child: case report. Pediatr Radiol 1999; 29(11):823-825.

12. RUBIN BP, HASSERJIAN RP, SINGER $S$ et al. - Spindle cell rhabdomyosarcoma (so-called) in adults: report of two cases with emphasis on differential diagnosis. Am J Surg Pathol 1998; 22(4):459-464.

13. PAPPO AS, SHAPIRO DN \& CRIST WM - Rhabdomyosarcoma Biology and treatment. Pediatr Clin North Am 1997; 44(4):953972. 
14. SHAPIRO DN, SUBLETT JE, LI B et al. - Fusion of PAX3 to a member of the forkhead family of transcription factors in human alveolar rhabdomyosarcoma. Cancer Res 1993; 53(21):5108-5112.

15. DAVIS RJ, D'CRUZ CM, LOVELL MA et al. - Fusion of PAX7 to FKHR by the variant $\mathrm{t}(1 ; 13)(\mathrm{p} 36 ; \mathrm{q} 14)$ translocation in alveolar rhabdomyosarcoma. Cancer Res 1994; 54(11):2869-2872.

16. PAPPO AS, SHAPIRO DN, CRIST WM et al - Biology and therapy of pediatric rhabdomyosarcoma. J Clin Oncol 1995; 13(8):21232139.

17. SCRABLE HJ, WITTE DP, LAMPKIN BC et al. - Chromosomal localization of the human rhabdomyosarcoma locus by mitotic recombination mapping. Nature 1987; 329(6140):645-647.

18. CORDON-CARDO C, LATRES E, DROBNJAK M et al. - Molecular abnormalities of mdm 2 and 553 genes in adult soft tissue sarcomas. Cancer Res 1994; 54(3):794-799.

19. KULLENDORFF CM, DONNER M, MERTENS F et al. Chromosomal aberrations in a consecutive series of childhood rhabdomyosarcoma. Med Pediatr Oncol 1998; 30(3):156-159.

20. WEBER-HALL S, ANDERSON J, MCMANUS A et al. - Gains, losses, and amplification of genomic material in rhabdomyosarcoma analyzed by comparative genomic hybridization. Cancer Res 1996; 56(14):3220-3224.
21. ARNDT CAS \& CRIST WM - Common musculoskeletal tumors of childhood and adolescence. N Engl J Med 1999; 341(5):342-352.

22. BEAHRS OH, HENSON DE, HUTTER RVP et al. - Manual for Staging of Cancer. $4^{\text {th }}$ ed. Philadelphia, Lippincott, 1992.

23. RAO VK \& HELMAN L - Sarcomas and malignancies of the bone. In: ABRAHAM J \& ALLEGRA C - Bethesda handbook of clinical oncology. Philadelphia, Lippincott, 2001. p. 237.

24. CRIST W, GEHAN EA, RAGAB AH et al. - The Third Intergroup Rhabdomyosarcoma Study. J Clin Oncol 1995; 13(3):610-630.

25. BAKER KS, ANDERSON JR, LINK MP et al. - Benefit of intensified therapy for patients with local or regional embryonal rhabdomyosarcoma: results from the Intergroup Rhabdomyosarcoma Study IV. J Clin Oncol 2000; 18(12):24272434.

26. PAPPO AS, LYDEN E, BRENEMAN J et al. - Up-front window trial of topotecan in previously untreated children and adolescents with metastatic rhabdomyosarcoma: an intergroup rhabdomyosarcoma study. J Clin Oncol 2001; 19(1):213-219.

27. BENJAMIN RS - Soft tissue sarcomas. In: SKEEL RT. - Handbook of cancer chemotherapy. $5^{\text {th }}$ ed. Philadelphia, Lippincott, 1999. p. $382-392$.

Received for publication on December 14, 2000 